\title{
Ethiopian Women; Agents and Subjects in the Shimglna (a Customary Conflict Resolution Institution): Amharas' Experience in Meket District, North Wollo Zone
}

\author{
Mekuanint Tesfaw
}

Debre Berhan University, Ethiopia

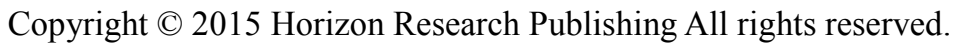

\begin{abstract}
The insufficiently studied issues of women in the Shimglna in Meket District of North Wollo Zone of Amhara National Regional state were the centre of the study. A qualitative approach with its data collection techniques (FGD, interview and observation) used. The Study found that women involve in marital conflicts and other conflicts. In search of solutions, the Shimglna plays vibrant roles. In the process, in some areas of the district, women participate as plaintiffs, defendants and rarely as mediators. However, in other areas of the district, the participation of women is limited, and there are still women whose participation is through their male relatives. While the participation of women in the Shimglna is low, conflicts involving women are addressed in equal basis with men. On the other hand, women's low turnout in the Shimglna has indirect adverse effects on the resolution processes of conflicts involving them. However, the belief of the society in which women are considered inferior and men are superior is not yet fully resolved. Moreover, the paradox between the legal jurisdiction of the Shimglna to address only family and personal matters restricts the scope of the Shimglna.
\end{abstract}

Keywords Women, Shimglna, Role, Meket

\section{Introduction}

The international community, the national governments and other stakeholders of the world's community have for long been taking diverse measures to foster the participation of women in all affairs of communities. Igniting the participation of women in the national and local peace processes is one of the focus areas of the stakeholders. Hence, the United Nations (UN) has been declaring conventions and resolutions to condemn violence and abuses against women and to improve their participations in the political, socio-economic and cultural aspects. Beside this, continental unions/organizations are in place in building on the attempts of the UN. Coming to the context of Africa, the African
Union subscribes to the UN and other stakeholders by adopting different instruments.

Ethiopia, as a member of the $\mathrm{AU}$ and the $\mathrm{UN}$, ratifies most of the international and continental instruments. The attempts of the country to ensure gender equality starts from the 1994/5 constitution. Article 35 of the constitution proclaims exclusively about the rights of women in communities. As a way of enhancing the rights of women in different domains of societal life, mainly on their family life, the government devised a Family Code in 2000, which best protects the rights of women. In putting into effect, such and other provisions of the constitution and the revised family code, the government works by devising policies with a special focus on women. The IIRR underlined that despite some changes registered; Ethiopian women continue to be the subject of marginalization [1]. During and in the post conflicts, women are the primary victims $[2,3,1]$. Women also experience arranged-marriage, enforced childbearing and heavy domestic and reproductive workloads $[2,3,1]$. In addressing such problems and resolving other conflicts involving women, women play minimal roles and their issues re taken as secondary in different communities of Ethiopia $[4,5,6,7]$. In counter, others argue that women play different roles in addressing conflicts either along with men or alone $[8,9,10]$ and the male based institutions address conflicts in equal basis irrespective of sex and other differences [3]. In addition, Ethiopian women are working to maintain peace and security across all provinces of the country. They, at least, play indirect roles in supporting, advising and condemning men in the peace process and in teaching children and women in the families and the villages about the importance of peace. In some communities, women serve as the symbol of peace $[11,12,1]$. As a matter of fact, there is no a research conducted on the study theme in the study area.

Having these paradoxes and contexts, conducting a research to analyze the status of women and the treatment of their issues in the Shimglna institution in the study area is a timely task. 


\section{Methodology}

The study is purely a product of qualitative method. It is due to the approach assists the researcher to have an in-depth understanding of the issue studied and its data collection techniques are interactive and humanistic with considerable degree of flexibility on due course of the research work [13]. The researcher has made interview with the local women residents who, by one or any other means, passed through the Shimglna 1 system, men elders, religious leaders and different government officials. Focus group discussion was the other tool has been employed to collect data. The researcher has made discussions with the women residents and men residents of the communities. Moreover, the researcher has used observation technique to collect the primary data. The researcher has observed some sessions of the Shimglna in addressing conflicts involving women and his experience in the area. In addition, related books, articles, reports and other documents used as sources of secondary data. In terms of sampling techniques, purposive and stratified sampling techniques have been employed.

\section{Overview of the Shimglna Institution in Meket District}

The Shimglna as one of the customary conflict resolution institutions uses its legal jurisdictions given by the constitution and the revised family code. Here, the Shimglna, as the researcher explored from all of the interviews and the focus group discussions, is a customary institution of conflict resolution, which is widely used by the community of Meket District to address conflicts of different natures. It resolves overall conflicts in line with the custom and the spiritual beliefs of the community, which persists over time. In the district, the conflicts involving women are the addressed by the Shimglna institution. In the district, the Shimagles 2 (mediators) are elected from the prominent individuals of the residents by the full consent of the conflicting parties on ad-hoc basis. The Shimagles must be individuals who know about the root causes of the conflicts and the backgrounds of the conflicting parties and respect the culture of the community.

\section{Conflicts Involving Women Addressed by the Shimglna}

In Meket district, women enter into different conflicts. One of the interviewees pointed out "in the district, women enter into conflicts. The conflicts happen with their husbands, brothers, mothers, sisters, children, neighbors, and others. In such a way, women take the issues to the Shimglna" [14]

Marital conflict is the frequently happening conflict involving married women at most. The participants of the FGDs held at all places pointed out that even though there are different conflicts in the study area, the conflicts in which

1 Shimglna is a Customary conflict resolution institution in Ethiopia, widely used by Amharas. Amhara is an Ethnic group mainly lives in Amhara regional State. According to CSA, Amhara is the second largest Ethnic group in Ethiopia next to Oromo ethnic group.

2 Shimagles are well-known individuals elected to mediate conflicts in the Shimglna institution. women often involved in are conflicts in the family. Either the wife or the husband often brings these conflicts to the Shimglna. Mesfin also supported empirically that the causes of those divorce cases which were brought to the police, court and the justice offices of the district and referred to the Shimglna are, men's superior behavior over the wife in managing families, in solving problems with discussion and administering property, land and money. In addition, the other potential cause for the spouses to get in to conflict is women's suspicion of their husbands for having extramarital relationship, men's extravagancy for Tella \& Katekala (local beer) and the likes $[14,15,16]$.

Women faced also other secondary conflicts in the district. These are land related conflicts, conflicts on property ownerships, property looting, and property inheritance. The fact that the conflicts are common to female headed households because widowed or divorced women are responsible for managing families and administering land and other properties. On the other hand, if their husbands are alive, men are in charge of administering and managing properties and land. Accordingly, mainly widowed or divorced women tend to be the ones engaging in such conflicts. Furthermore, women face gender-based violence such as rape, abduction and early marriage. Though common across both groups of women, it is sever to unmarried and widowed women.

Because of the natural sex of women and their weak physical fitness, some male members of the community abuse women. Few male members of the community need to satisfy their sexual gratification by abusing the rights of women. Moreover, the culture of the society makes women to be subjects to early marriage. Mesfin, and Mulu, stated that the gender-based violence women face in the study area is different from the conflicts involving men. It is because the violence such as abduction, early marriage, and rape in most instances happened due to the biological sex of women. Moreover, of course, the culture of the society in which women are believed to be inferior and male are superior make them to be abused[15,17]. A woman interviewee states that "Since women are physically weak and unable to defend themselves from the attack of men, men rape and abduct women to satisfy their sexual gratifications"[10].

Moreover, a woman key informant in Filakit, mentioned:

The community especially men have a belief that we (women) are inferior to men. The community (especially men) undermines us who are in charge of leading our families through selling Tella and Katekala (local beer). Men need either to sleep with us or leave without paying money for the Tella or Katekala for they drank [18].

The common causes of the conflicts in the study area are related to economic factors. The prolonged poverty and unemployment of the community members creates conflicts in and outside of families. Mainly, females face problems in the community, especially, with their husbands and ex-husbands. Rearing children and leading the family is one of economic causes of the conflicts in the family. Most of the 
time, after having children, men leave them without offering any economic support to feed their children and lead the family. This leads women to accuse their husbands and ex-husbands. As such, women take the issues to the Shimglna and sometimes to the state legal institutions. Sheik Umer, a judge in the Sharia Court, stated that:

Most of the time, women bring economic cases to our Sharia court before and after divorce. The cases are in search of money and other resources to lead their family and to cover costs for their children. The claimants tell that their husbands leave them without giving money and other things and move to other areas [19].

The women focus group discussants in Weketa stressed that the cause of conflicts are rooted from economic factors. They further explained the acuteness of the issue as follows:

Our surrounding is a drought prone area. To survive, we strive to have resources and money. In such a way, some of us seek to steel property of others. In addition, our poorness makes us intolerant of each other. Thus, conflicts happen among the haves and have not's and among have not's themselves in search of resources [20].

The above data reveal that there are different causes for conflicts involving women in and out of their families in the study area. Most importantly, the economic cause is the root cause for all conflicts in the area. In addition, family management, land and property ownership, land pushing, property looting, the cultural status of women in the community, extra-marital relationship and men's behavior of superiority and extravagancy are among other causes.

\section{The Different Roles of Women in the Shimglna}

The findings of this research proved that the participation of women in the Shimglna in the community of Meket district shows that the participation of women in the Shimglna varies from area to area. In some places, they take part as plaintiffs, defendants and sometimes as mediators in conflict resolution activities. However, in other areas of the district the participation of women, especially as mediators, is very much limited. According to Mulu, "women have never been priests and mediators in the history of this community. Nevertheless, in claiming and defending their issues, they take part in the Shimglna. Yet, still there are women who represent their relatives to present their issues" [17].

In supporting this notion, the head of the revenue office of the district, Amsal, notes:

Currently, women do not have problems to present their issues in the Shimglna. They have the rights to elect the Shimagles and accept or reject their decisions. However, as per the cultural practices of the community, they have never been Shimagles and sometimes they are represented by male relatives to present their issues [21].

The religious leaders from Islam and Ethiopian Orthodox Christianity support the argument that women claim and defend accusations in both the state court and the Shimglna. Nevertheless, due to the cultural practices of the society inherited from the past, women have never been mediators in the Shimglna. Nonetheless, in both religions, there are no religious principles that prohibit women not to mediate conflicts $[19,22]$. On the other hand, the data collected from the FGD with men held in Agrit revealed that not only as accusers and as defendants, women participate in the conflict resolution proceedings of the Shimglna as mediators in addressing conflicts and other issues among women themselves or between women and men. A discussant in the above FGD stated, "While I married my wife, the Shimglna process of our marriage was facilitated by a woman. In addition, women used to mediate conflicts with us. In the processes, they generated solutions and led the proceedings efficiently" [23].

And, a woman participant in the FGD shares her experience of conflict resolution as follows:

I have mediated conflicts along with women and men. The conflicts were among men, between women and men and among women themselves. I have accomplished the task equally with men. However, men were not interested to mediate conflicts with me. As such, I declined the task [20].

KI-B states that she frequently mediates conflicts among women in the family and in the community. Sometimes, she mediates conflicts involving women along with men. In the mediation processes, she takes parts, and she has effectively mediated conflicts equally with male mediators [24].

The above data show that though it is in rare cases, women mediate conflicts and manage marriage and the family issues under the umbrella of the Shimglna institution.

Women's level of negotiation and interaction in the Shimglna institution and its conflict resolution activities starts with their vote in the election of the Shimagles and in accepting their decisions. In the study area, the FGDs discussants and interviewees stated that even though the election of women as mediators is rare, the election system has not limitations. Both conflicting parties are free to elect and refuse the mediators. In the process, women have full rights to elect and to be elected. However, even women themselves elect men mediators rather than electing women. A key informant fortified the notion that "in the Shimglna process, the election of Shimagles is based on the consent of the conflicting parties. The election and decisions of elders put into effect as long as it receives the full consent of the conflicting parties including women"[24].

A key informant shares his experience in the court as follows:

When marital disputes come to the court, we refer it to the Shimglna. We make the husband and wife to elect Shimagles they trust. Then, when the Shimagles come up with solutions, we ask both conflicting parties whether the decisions are convenient to them or not. If they give their full consents, we endorse the solution as binding; if it is not, we extend it for further investigations [25]. 
The FGD discussants pointed out that the Shimagles are elected based on the consent of the disputants. In the election process, women have the right to elect and to be elected. There is no any law or provision of Shimglna institution that prohibits women not to be Shimagles. In the process, there is a growing tendency of encouraging women to present their issues freely as plaintiffs and defendants [26].

The researcher's observation of the following conflict resolution proceeding of the Shimglna best describes and summarizes most of the discussions in this section, the preceding and succeeding sections of this research.

\section{Case 1: A Conflict of neighbors addressed by the Shimglna}

Enaney and Mikir, who are widowed neighbors, had a long time conflict on grazing land and other property-lootings. The conflict persisted for at least five years with no war and no peace. The case was taken to the Kebele Social Court and the Kebele Administration at different times, and the court and the kebele administration have passed decisions on it. But, the decisions did not halt the conflict. To resolve the conflict from the source and to convince the neighbors, the relatives of the two women had made influences. This attempt of the elder relatives of Enaney and Mikir ended on 26 December 2014 in Weketa Mariam. By the continual efforts of the elder relatives from each side, the two women elected five Shimagles to whom both of them consented. One of the Shimagles was a priest, and one of the other Shimagles was a woman. The processes started with religious prayers and oath to reveal the facts to the elders' council. The first claimant who presented her issue was Mikir, and Enaney continued. The women have given the chance to present their issues and to counter each other for more than two times. After hearing their accusations and counters, with the support of their knowledge to the conflict, the Shimagles became aware of the real causes of the women's conflict and interests. In the process, since the case was between two women, the woman mediator has played a significant role in investigating the real causes of the conflicts. She used her experiences observed during their quarrels at several times in the village. Then, the Shimagles came up with solutions. They presented the possible solutions to Mikir, Enaney, and the relatives of each. Mikir and Enaney with their relatives found the solutions proposed by the Shimagles as the win-win solutions. Then proceeding ended with religious prayers and blessings for the women, relatives and the elders and followed by reconciliation programs by drinking Tella and eating food. For the ceremony, each of the women (Mikir and Enany) contributed 10 ETB and four Injera 3 with Wott4, and two people from each side have contributed 5ETB. Finally, the program ended up with another blessings and prayers led by

3 Injera is a fermented traditional food made from Teff flour (a native grain) 4 Wott is a food eaten with Injera in Ethiopia, which is composed different spices and oil.

\section{the priest Shimagle.}

Women play important roles in resolving conflicts in the families and neighbors. Bamlaku (2010) explored that women play significant roles in preaching and teaching peace at home to their children and out of home. In Meket district, the roles of women in building up peace in the families and the villages are similar with the above circumstances. The respondents from different areas of the district underlined that when disputes happen in the families, mainly among children and among other women members of the families, it is a mother or an elder woman who manages and mediates it. A dispute will be referred to the husband or other elder male member of the family when that is out of the control of women. According to the participants in the FGDs and interviews, in the women headed families, women are responsible to manage the families. In so doing, they are responsible to socialize children and to resolve conflicts effectively without the help of outsiders. However, in rare cases, male neighbors and other relatives interfere to mediate grave circumstances in the families. The key informants and FGD participants add that women address conflicts between children and between women in neighbors and villages. In addition, in the FGD with men held in Dibko, participants described the immense roles of women in making peace in the society that:

Our women are the peacemakers in our villages. Their roles start with advising and preaching us and our children to tolerate each other. When conflicts happen, they force us to resolve our conflicts peacefully. If we are hesitant to resolve our conflicts, they impose different sanctions on us. For instance, they ignore us to talk to them and our children, they deny us sexual intercourse, and even they need to divorce us [27].

In addition, in the district women sanctioned their sons to not to involve into conflicts and to resolve conflicts through peaceful means by laying down under their knees and by using different sayings. The sayings include;

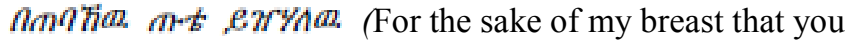

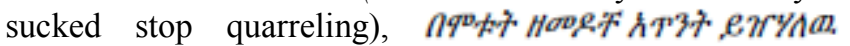
(literally, I forbid you with the bone of my dead families),

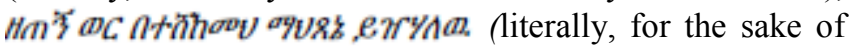
my womb that did hold you for nine months stop fighting) and etc.[27].

The researcher's experience he acquired while he has been growing in the area starting from the late 1990s revealed that women play great roles in socializing children and shaping the day-to-day lives of the families. The community uses different sayings to describe the vital roles of women in the

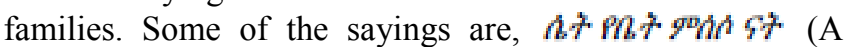
woman is the pillar of the house),

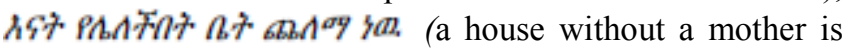
dark), ASt PAtrin Has St (a mother is a crown of the

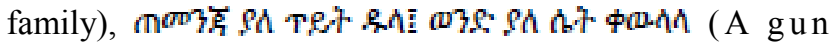


without bullet is Dulla 5 as a man without a woman is

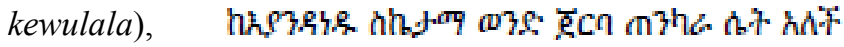
(Behind every successful man, there is a strong woman) and the likes.

In summary, according to the interviews with government officials, local residents and the FGD participants held at all places and observations of some sessions of the Shimglna the trend in the district is showing progress. While women face conflicts and their rights abused in and out of the families, they tell to their relatives freely and take to the Shimglna and sometimes to the police offices and the courts. In the process, they elect the mediators, rarely including women, present their accusations, and defend the accusations without any fear. The solutions proposed by the Shimagles are binding as long as accepted by the conflicting parties. Thus, women in the study area have been participating in the conflict resolution proceedings of the Shimglna as plaintiffs, defendants and sometimes as mediators. However, there are instances in which women present accusations and defenses through their male relatives. And their participation as Shimagles in resolving conflicts is very low. Different from the previous findings, according to the researcher's exploration from his observation and the participants from all FGDs and interviews, there is no any female-based customary conflict resolution institution, established to resolve conflicts involving women in Meket district. The only customary conflict resolution institution of the community is the Shimglna.

\section{The Shimglna in Addressing Conflicts Involving Women}

The other issue need to be answered is how the conflicts involving women be addressed in the Shimglna while the participation of women is low. In the study area, women's FGD participants stressed that though in some instance women have low participations in the Shimglna, especially as mediators, the conflict resolution processes are based on equality and truth [28]. In another FGD held in Debrezebit, men elder discussants supported the notion that the low participation of women in the conflict resolution activities of the Shimglina does not have negative impacts on the fairness of the decisions. It is because men have mothers, sisters, daughters, wife and other female relatives. So, making biased decisions is considered as hurting mothers, wives, sisters, daughters and other female relatives. The community of the district often uses sayings to justify the fairness of decisions. Some are; त̃र

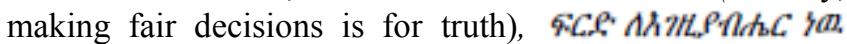
(its literal meaning is making fair decisions is for God),

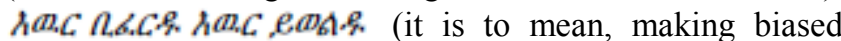
decisions leads to have blind children) etc. [29]. Some of the government officials also subscribe to this idea of the local residents. Gedam has supported the above idea in the way that the Shimagles in the Shimglna are elected by the consent of the conflicting parties. And, the decisions of the

5 Dulla is a stick
Shimagles put into effect based on the agreement of the conflicting parties including women. As such, the mediation processes are based on equality of men and women. There is no discrimination in consideration of sex, age, religion, race, and wealth, etc. [16].

These data show that in the areas and places where the participation of women in the Shimglna institution and its conflict resolution activities are low, the conflicts involving women are addressed equally with men. The Shimagles are not working only for men; rather, they work for all segments of the society without any discrimination.

As well, the following case demonstrates this fact and other discussion of the research.

\section{Case 2: Marital conflict handled by the Shimglna}

It was on 17 December 2013. Dembere brought a divorce case against her husband Fetene to the Meket District's First Instance Court. The accusation to the court and the result of investigation of the Shimglna revealed that the causes of the conflict were the disagreements with her husband in managing their family, administering their property, her suspicion of her husband that he had extra marital relations, and he was extravagant for Tella and Katekala (local beer) in the local bars. The court made the next appointment on 02 January 2014 to hear the defense of the husband. Then, the court has given a cooling time to the spouses to resolve their conflicts in line with their culture. Then, both of them elected one elder who trusted by both of them. The elected elder has the responsibility of managing the process in Yebete-zemed Gubaye (Council of Relatives). On 08 January 2014, the elected elder has initiated the spouses to elect the other four Shimagles with their full consent in Meskel.

The Shimglna process then postponed for 12 January 2014 with the aim of the Shimagles to have time to collect information about the conflict. On the morning of 12 January 2014, the Shimglna process started with religious prayers by the help of their confessor father and consultations by the elders and relatives. Some of the rhetoric used to convince

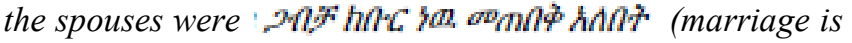
sacred, it has to be protected),

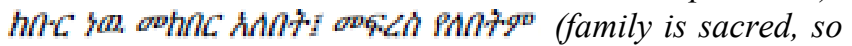
it has to be respected but do not disintegrate it), and the likes. In such a way, the wife has presented her claim and accusations to the council of elders followed by the husband. The Shimagles made intensive discussions with the spouses together, with the husband and wife separately and among themselves without the presence of the spouses and nearest relatives.

Then the council of elders reached on a decision that the spouses should manage their family and administer their property cooperatively, solve their problems through discussions, and the husband should decline from his extravagancy and avoid his extra marital relationship. The elders presented the proposed solutions to the spouses and the relatives. The decision was in consideration of the fate of the children and the family. Both the husband and wife found 
the decision is fair and relevant for the solidarity of their family and their children. The Shimglna process ended with blessings and religious prayers.

On 20 January 2014, the spouses prepared ceremony and invited the elders and other relatives in their home. By then, the spouses reconciled their problems and promised to live peacefully with their children. The ceremony ended by blessings of the elders and the relatives and by religious prayers and rituals with the help of their religious confessor. The blessings were AILPAhC U. (may God be always with you);

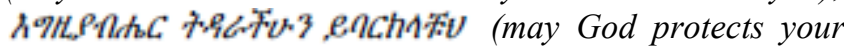

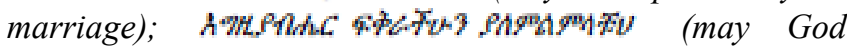

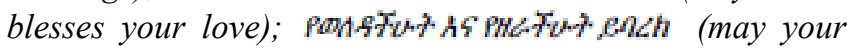
children and your cereals be blessed); h.t hatc st hindat. (a female is sacred, respect your wife);

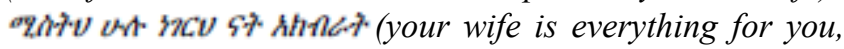

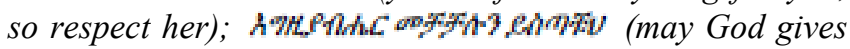
you tolerance) and etc.

On the other hand, the less involvement of women in the Shimglna as plaintiffs, defendants and mediators has indirect negative impacts to address conflicts involving women. Even though the mediators work to make peace sustainable in the community, they sometimes misunderstand the issues of women, and they make unfair decisions. Mulu, stated that the day-to-day change of the community's attitude exerts changes on the participation of women in both the government and other community's activities. The Shimglna often resolves conflicts based on equality. In some areas of the district, women are participating at least in presenting and defending their issues. However, in other areas of the district, the less representation of women in the Shimglna needs attention of stakeholders. This less involvement of women exerts problems on the Shimglna to address conflicts involving women equally with the issues of men. Thus, there are tendencies to hurt the interests and rights of women. In addition, there are issues of women, which are understood exclusively by women themselves. In resolving such conflicts, having a woman Shimagle in the Shimglna processes is very important. As such, she can make the Shimagles aware of the issues; thus, fair decisions will be made. Furthermore, women are close to information. When conflicts happen in the villages, women are the first to hear and know the root causes of the conflicts. Therefore, the less involvement of women influences the processes of the Shimglna to resolve conflicts endurably [17]. Another woman interviewee further stated, "most rural women fear to tell their issues to male Shimagles. In fact, there are also secrets, which cannot be told to men. This becomes a problem to the Shimglna system" [21].

In the community, religious leaders strengthened the above notion that men Shimagles resolve conflicts involving women irrespective of sex, religion, wealth, marital status and other differences. However, sometimes, there are issues have direct relationships to their biological sex; they do not want to tell for men. As such, male Shimagles misunderstand their issues, and the decisions have the tendency of bias on the issues of women [30, 31]. FGD discussants in Weketa also supported that the less participation of women in the Shimglna process has adverse effects in addressing conflicts involving women. This creates problems on the attempts of mediators to understand the underlying causes of conflicts involving women and to heal the conflicts from the source [20].

A woman key interview also supports the scenario by adding her experience that:

I heard two women who accuse the Shimagles for they misunderstood their issues. The issues are their husbands have a problem of satisfying them sexually. Firstly, the women feared to present, and second the Shimagles failed to understand them. Then, the Shimagles decided that the issue is minor; thus, spouses should live together [18].

\section{Major Factors that Challenge the Shimglna}

As discussed above, in different areas of Meket district, women paly different roles in the Shimglna and conflicts involving them addressed equally with men. However, in some other areas of the district the roles of women as plaintiffs, defendants and especially as mediators are very low. Male members of the community are in charge of women to present their issues in the conflict resolution proceedings. Also, in some instances, conflicts involving women are insufficiently addressed. These low involvements of women and mistreatment of their issues come due to different factors. In Meket district, though it makes the people to resolve conflicts via the Shimglna, the cultural practices of the community inherited from the forefathers unfit with the rights and freedoms of women deters the participation of women and the resolution of conflicts involving women in the Shimglna. Even though there have been changes, the community, including women themselves, still believes with the superiority of men and inferiority of women. The society believes that men are the symbol of God; so that, they resolve conflicts fairly. The socio-economic role women assumed within the society makes them to remain at home and to leave other activities outside of home to males. Thus, it restricts women not to participate in Shimglna system of the society. Some of the common proverbs hinting

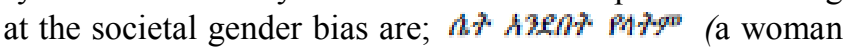
doesn't have words), pht di henthing" (women's word

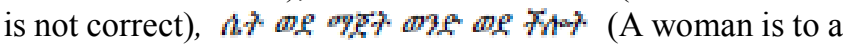

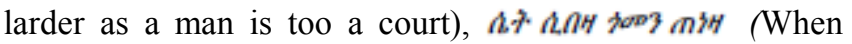
there are many women, the cabbage will be spoiled),

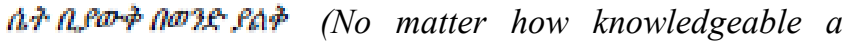
woman is, it is only a man who could bring a wise finish),

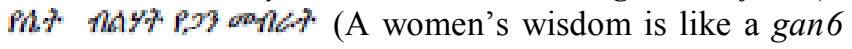

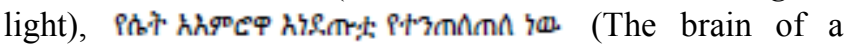

$6 \mathrm{Gan}$ is a big pot used to carry water like barrel 
woman hangs like her breast), etc.

Furthermore, sometimes, the society makes women be silent in the conflict resolution processes and to accept the decisions of Shimagles, which are in favor of men or other women. In the study area, though there have been changes coming in time because of the work of the government to realize gender equality and the socio-economic, political and cultural changes of the world, this experience sometimes works. Women respondents of the FGDs and interviews of local women residents asserted that the community members exert influences on them to accept the decisions of Shimagles with its problems. Sometimes, the relatives and the confessor fathers condemn and ostracize women who claim that the decisions of Shimagles are against their interests. Women who refused the decisions of Shimagles are considered to be refusing the norms and values of the society and they go against the greater good of the society. Thus, this affects women not to have access to customary justice equally with men, and makes them to go further (to state institutions) in search of better solutions.

The other factor comes from the community itself and which delays the work of Shimglna is weak organization of the Shimglna. This is reflected in the loose structure of the Shimglna and the lack of written laws that guides the conflict resolution activities. The absence of written laws makes the Shimglna sometimes to stick on only the cultural practices unfit with the rights and freedoms of women. Here, the lack of well-organized structure and the absence of written laws are frequently creating problems on the responsibility of Shimagles; also, the Shimagles stick on the outdated practices, which are contradicting with women's rights.

In the court, the written laws guide us to bear our responsibilities. They are also easy to revise in line with the existing developments. Moreover, having permanent structure makes us to be available to customers. However, even though it is time immemorial heritage of the community, the absence of permanent structure creates problems in accessing the Shimagles and on their responsibility. And the absence of written laws makes the Shimagles to stick on the outdated cultural practices that hurts the interest of women [15].

Shortage of stationary materials and finance for different costs and lack of office challenge the Shimagles in mediating conflicts. The illiteracy of Shimagles and the other members of the society is a shortcoming that restricts them to understand things easily and to fit easily with the time-to-time changes. The illiteracy of mediators creates problems on their understanding of rights of women. Thus, they distort the issues of women in the way they intended to present and make biased decisions against their interests. Here, sometimes, men counters in the form of corruption with the local bars and cultural and religious networks of men manipulate men mediators.

Mulu stated that though the government recognizes the existence of the Shimglna as an institution and its immense roles, its support and assistance to halt this problem is

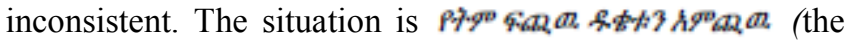
effect excuses the means or its literal meaning is where ever you grained bring the powder) [17].

The other factors, which hinder the conflict resolution activities of the Shimglna, come from the government. In fact, as discussed above, the constitution and the revised family code determine the competence of customary institutions to see personal and family issues with the prohibition to address criminal issues. However, the Shimglna resolves all kinds of conflicts. As well, the community claims the Shimglna to address all kinds of conflicts; thus, sustainable peace restored. In due course, by depending on the legal jurisdiction given to the customary institutions, the government of the district prohibits the Shimglna to decline from addressing criminal matters. Even, sometimes, the government says the Shimglna is serving as a bush for the criminals. It is covering wrongdoings. This creates suspicions from the side of Shimagles that they are not sure as their decisions will have acceptance by the government and their personal lives are safe. As a result, the Shimagles decline to address whatever conflicts in the community. This leads the community, including spouses, to bring cases to the state justice institutions in search of solutions. Nevertheless, since the state justice institutions focus on preventing conflicts for short period, it leads for further conflicts in the forms of retaliation and vengeance. Thus, makes the society unstable. The FGD participants described the scenario in the way that "our Shimglna has its own methods of sanctions and compensation. However, the government limits its jurisdiction address only family and personal matters. This leads us to retaliation and vengeance" [27].

In reacting to the statements and claims of the elders about the legal jurisdiction of the Shimglna as a customary conflict resolution institution, government officials who are close to law specified that in the law of the country customary conflict resolution have jurisdictions to see only family and personal matters. Thus, the government justice systems do recognitions to the Shimglna as a customary institution to be confined with the family and personal matters. Although it is from above, the society claims that the prohibition of the Shimglna not to address criminal matters and violence by the government have been creating further conflicts and fragmenting their relations $[14,15,16]$.

In addition, FGD participants stated that, there are some government officials who aggravate conflicts and advise conflicting parties to take cases to state justice institutions instead of advising them to resolve their conflicts via Shimglna at hand. For example, when women take marital cases to the District's and kebeles' Women, Youth and Children's Affairs Offices, some officials advise them to accuse their husbands in the police and the court. This aggravates conflicts and makes difficult the situation to the Shimglna to resolve the cases easily [26]. Mandefro also recognizes that, there are some government officials who see things easily without making cost benefit analysis for the community and the state at large. They see issues from one 
direction and from their interest without taking in to consideration the solidarity of families [14].

The recruitment of the Shimagles in the peace committee, in the social courts, and other administrative wings of the district and different kebeles 7 creates problems on the trust of Shimagles and acceptance of their decisions. A respondent stated the issue as follows:

I have been mediating conflicts in the area before and after I become a member of peace committee of the District. But the trust of the community before I become a member of the peace committee was high. But currently, only some people elect me as a mediator. The same is true for the other elder members of peace committee and other offices [25].

In the focus group discussion participants emphasized that the recruitment of the well-known elders in the peace committee, the social courts and other administrative posts of Kebeles and the district results in eroding their trust to legitimacy of elders. The society suspects them that they are politically manipulated by the ruling regime [26].

Sometimes, people refuse the decision of Shimagles, which are believed to be fair. It is another delinquency to the Shimglna as an institution and its conflict resolution activities especially in resolving conflicts involving women. As the researcher realized from the participants of all FGDs and interviews, there are people who have problems in accepting the elected elders and their decisions. Even the decision is in favor of them, they always refuse it. And there are people who give advice to the conflicting parties not to agree on the decision of Shimagles instead of lobbying them to resolve their problems at hand via Shimglna. This makes the Shimagles to dislike their conflict resolution activities they love so much. Also, there are people who waste the time and resources of the Shimagles.

The legal understanding of the community in the study area is very law. Even though there are changes come in time, the illiteracy of women as compared to men in the community makes them ignorant of law and the procedures and mechanisms of conflict resolution activities of the Shimglna and the state justice institutions too. As result, male members of the community easily exploit them and they cannot defend their rights in the state institutions and the Shimglna equally with men. Further, this situation makes women to have low participations in the Shimglna. This leads them to be silent and sometimes to claim and defend accusations by their representatives. This greatly hinders the negotiation and mediation processes of Shimglna in resolving conflicts involving women. Women FGD participants note, "we are not lucky to enjoy education. This is the major source for all of our problems we face in and outside of our families. It restricts us to stay in home with our problems. Thus we leave everything outside of our home to men" [20]. Mesfin strengthened the notion that being ignorant of the laws and procedures of the Shimglna is not

7 Kebele is the smallest administrative structure of the country's political organization limited to only women and. It is a common problem to most of the community members. This problem, in general, makes the people to believe with inferiority of women than men [20].

\section{Conclusions}

The objective of this research was to study the status of women in the Shimglna with a special emphasis on Meket District in North Wollo Zone of Amhara National Regional State. Firstly, different conflicts, specifically conflicts involving women have been investigated. The most frequent conflict is marital conflict involving married women at most. There are also secondary conflicts that happen out of the families. Shimglna as the vibrant customary conflict resolution institution addresses such and other conflicts.

Exploring the different roles of women in the Shimglna was one of the core points studied. The roles of women in the Shimglna vary from place to place. In some areas of the district, women participate as plaintiffs, defendants and sometimes as mediators. However, in other areas, still there are women who present their issues in the Shimglna by their male relatives, and their participation as mediators is very limited. In the district, there is no any female-based institution that operates for resolving conflicts and for protecting the rights of women. On the other hand, women play numerous roles in handling conflicts in families and neighbors. They are believed to be an engine of peace in the families.

Appraising the experience of the Shimglna in resolving conflicts involving women, when their involvement is low was the other major them of the study. In Meket District, while the participation of women in the Shimglna is very law, the experience of Shimglna in handling of conflicts involving women has two dimensions. The first dimension is that though women have less participation in the Shimglina as plaintiffs, defendants and mainly as mediators, the male mediators handle conflicts involving women based on equality. The other divergent view is that the less participation of women in the Shimglna has indirect impacts on the work of the Shimglna in addressing conflicts involving women. It is due to male representatives present their issues distortedly; also, due to women have secrets, which should not be told for men. Furthermore, women also fear male mediators to tell their issues vividly. Thus, male mediators misunderstood their issues; thus, make biased decisions unconsciously. Though it is rare, there are mediators who are manipulated by male counterparts in the form of bribe.

The Shimglna is affected by different factors in addressing conflicts involving women. Though there have been changes, the attitude of the community to give priority to the issues of men is one of the factors. In addition, the paradox between the legal jurisdictions of the Shimglna to address only personal and family matters and its actual practices in 
addressing all kinds of conflicts is the other factor creates tensions between the local people and the government. In fact, the recruitment of the well-known elders in the social courts, peace committees and other government posts results in eroding the legitimacy of mediators in the Shimglna. These factors make the issues of women as secondary.

\section{Dedication}

This Article is dedicated to my beloved wife-to-be; she has seized the city of my heart, Sara Daniel and my father Tesfaw Birlie, who is enormous

\section{REFERENCES}

[1] IIRR. Culture cross roads: Ethiopian women in peace-building. Kenya, Nairobi: IIRR; 2009.

[2] Ayalew G. Customary laws in Ethiopia: A need for better recognition. Denmark's National Human Rights Institution; 2012.

[3] Meron Z. 'Ye Shakoch Chilot' (the Court of the Sheikhs): A traditional institution of conflict resolution in Oromiya Zone of Amhara Regional state, Ethiopia. African Journal on Conflict Resolution, volume 10, Number 1, 2010, 63-84.

[4] Alula P. Getachew A, eds. Grass-roots justice in Ethiopia: The contribution of customary dispute resolution. Addis Ababa: Centre francais d'études ethiopiennes; 2008.

[5] Tarekegn A. Hannah H. (eds.) Making peace in Ethiopia: five cases of traditional mechanisms for conflict resolution. Addis Ababa: Peace and Development Committee; 2008.

[6] Gidey D . Traditional mechanisms of conflict resolution in Ethiopia: An introductory inquiry into the salient features of traditional conflict resolution mechanisms in the Gurage, Amhara, Oromo and Tigray societies. Addis Ababa: Ethiopian International Institute for Peace and Development (EIIPD); (2000).

[7] Bamlaku T. Women in Conflict and indigenous conflict resolution among the Issa and Gurgura clans of Somali in Eastern Ethiopia. African Journal on Conflict Resolution, volume 10, Number 1, 2010, p. 85-110.

[8] Kiya G. The efficacy of benediction and prayer among the Amhara Society: An anthropological study of the religious rituals of 'Erfo Mereba' and 'Shenecha' around Rayya Qobbo Wereda of North Wollo Zone (Unpublished Master's thesis), Department of Social Anthropology/Addis Ababa University; 2013.
[9] Merhatsidk M. The wisdom of mediating family disputes in the Awramban community: Is it sustainable and worth replacing. In Gebre Y, Fekade A. and Assefa F. (eds.) (2011), Customary dispute resolution mechanisms in Ethiopia. Addis Ababa: The Ethiopian Arbitration and Conciliation Center. 203-225.

[10] Tolosa M. The Siinqee: Women's institution for conflict resolution in Arsii. In Gebre Y, Fekade A. and Assefa F. (eds.) (2011), Customary dispute resolution mechanisms in Ethiopia. Addis Ababa: The Ethiopian Arbitration and Conciliation Center.203-225.

[11] Guday E. Eskinder T. Gender relations in access to and control over resources in Awramba community of Amhara Region, Ethiopia. Ethiopian Journal of the Social Sciences and Humanities, volume 9, Number 2, 2013, 1 -36.

[12] [12] Abdi M. The role of Somali women in the search for peace. In UNESCO (2003), Women and Peace in Africa: Case studies on traditional conflict resolution practices, 75110 .

[13] John C. Research design: Qualitative, quantitative and mixed methods Approaches. 2nd Edition. Thousand Oaks: Sage Publications Inc; 2003.

[14] Interview with Mandefro, 16 January 2014, Filakit

[15] Interview with Mesfin, 17 January 2014, Filakit

[16] Interview Gedam, 10 January 2014, Filakit

[17] Interview with; Mulu, 20 January 2014 Filakit

[18] Interview with KI-C, 17 January/2014, Filakit

[19] Interview with Umer, 16 January 2014, Filakit

[20] FGD with women, 01 January 2014, Weketa

[21] Interview with Amsal, 18 January 2014, Filakit

[22] Interview with Gedam, 18, 2014, Filakit

[23] FGD with men, 15 January 2014, Agrit

[24] Interview with KI-B, 14 January 2014, Geregera

[25] Interview with KI-A, 18 January 2014, Filakit

[26] FGD with men, 13 January 2014, Flakit

[27] FGD with men, 01 January 2014, Dibko

[28] FGD with Women, 15 January 2014, Debrezebit

[29] FGD with men 13 January 2014, Flakit

[30] Interview with KI-D, 08 January 2014 Anjeb

[31] Interview with KI-E, 09 January 2014, Arbit 